\title{
4. History and His-Story
}

\author{
What is History then? \\ Providence, accident, irony, or Fate? \\ Turgenev, to Pauline Viardot, \\ 15 May 1848
}

History and His-story: a fortuitous verbal association perhaps, but they both figure prominently in Strindberg's work and are closely linked at various points and in different ways throughout his career. From Greece in Decline in 1869 and Master Olof in 1872 via the two-volume history of The Swedish People of 1880-82, the four volumes of short stories on historical subjects that he wrote in the 1880s and 1900s, to the eleven major plays on Swedish historical themes written in the decade between 1899 and 1909 and the three 'worldhistorical plays' written in 1903 - the past of Sweden and (especially in his later years) the history of the world were, like his own past, one of Strindberg's most constant preoccupations throughout his life, a life that he assiduously documented as an item in the annals of his own times. "Why rake up the past?', Queen Maria Eleonora asks in his most ambitious history play, Gustav Adolf (1900). 'Because the past rises up' (Därför att det förflutna står upp [SS 32, 232]), replies the king, echoing numerous such comments to do with repetition, recurrence and the return of the past in several of Strindberg's more evidently personal dramas. 'Everything repeats itself [Allt går igen, SV 44, 69]: the web of past actions with its entangled plot of guilt and suffering in which the protagonist is caught up returns to haunt the present, whether it is the present that Gustav Adolf inherits from his predecessors in the House of Vasa; the past that comes increasingly to dominate the present of the protagonist in (for example) To Damascus, The Dance of Death, and The Burned House; or the material underlying any of the accounts of his own past that accumulate as Strindberg lives on.

Given the numerous ways in which the genres of autobiography and history were readily associated during the nineteenth century, this link is hardly surprising. Conventionally, both historian and autobiographer regarded the past as a series of events that required 'emplotting' by way of narrative into an order or sequence whereby that past would be rendered intelligible to the 
reader. Neither historian nor autobiographer generally regarded the way in which the narrative was told as unduly problematic, and certainly not in the problematic mnemonics of the self and its representation that have evolved over the last one hundred years. One merely began at the beginning and continued until the end, observing in the process the linear, chronological unfolding of the subject in time, whether that subject was personal, national, or universal in scope. If misgivings arose, it was mainly in so far as the facts on which the respective accounts were based might be considered 'right' or 'wrong'

Thus history, during what Hayden White has called its 'mature' or 'classic' phase, lasting from around 1830 to 1870 , was widely regarded as dedicated to the objective pursuit of truth. ${ }^{1}$ Given the salient documents judiciously used, it might produce an accurate picture of the past that would disclose the formal coherence of man's life in time. What eventually underpinned this faith was not, however, the order or disorder of the available archives. Rather, it was a conviction shared by the historian with a majority of those who produced extended narratives, both fictional and factual and with which the century abounded, that this data could be represented in language as a story. Indeed, the paradigm for the writing of history or biography is still in many respects provided by those narrative conventions established for the nineteenth-century novel by Scott and Balzac, for whom fiction was always so deeply engaged with history, both past and present, and by whom the individual life was invariably portrayed as in complex interaction with the social existence of the period in which it was lived.

It is therefore perhaps worth noting at the outset a certain curiosity in the apparent confidence that Strindberg retained in history as an unfolding source of emplotted meaning, even after the Inferno crisis, when, as a dramatist, he was otherwise engaged in dismantling the dependence of drama on conventional plot-making. In this context, both the attempt in his essay 'The Mysticism of World History' $(1903)^{2}$ to arrive at a synthesis of historical events conceived as story and the very writing of history plays on into the present century appear passé; on this account at least, Strindberg would seem to be at odds with a standpoint that is common in a great deal of modern writing, in which - as once again Hayden White has remarked ${ }^{3}$-history is regarded with suspicion and often with despair (a view shared, for example, by James Joyce's Stephen Daedelus, who famously regarded history as a nightmare; by Nietzsche, with his feeling for the way in which the historical sense paralyses action and turns men into shades and abstractions; by Ibsen, whose Hedda Gabler suffers from a surfeit of history in the guise of the abstracted Tesman; and even perhaps by George Eliot, whose Dorothea exchanges history, in the form of Casaubon, for art, in the person of Will Ladislaw). There seems, in short, something of a contradiction between the modernist writer who created $A$ Dream Play and The 
Ghost Sonata, and the tenacious pursuer of order and meaning in the events of history, in which the latter is conceived (in 'The Mysticism of World History') as still retaining the vestiges of some sacred masterplot - 'The Conscious will discovered in world history,' as he calls it in his correspondence [XIV, 244], which establishes the framework through which the world is organized and explained.

Perhaps, however, this apparent faith in history reflects a desire on Strindberg's part for the past to make sense, for in that case maybe his own life would too. Here, as regards autobiography, the issue is more complex. Certainly, the assumption at the heart of much nineteenth-century autobiographical writing was that it had likewise to do with the faithful, if more subjective, reconstruction of past events in their proper order and significance, a sequence that, if once established, would yield a definitive account of the life in question precisely because of the authority its teller could claim on his or her own behalf. This, of course, was a strategy that Strindberg employed in the programmatic interview that he wrote to introduce the first volume of The Son of a Servant:

How is one to know what goes on in other peoples' minds; how can one know the complicated motives behind someone else's actions; how can one know what they said in an intimate moment? Well, one invents... one knows only one life, one's own. [SV 20,373]

By definition, of course, autobiography - like history - comes after the event it records and, in the act of writing, it also constitutes its subject by applying to it various strategies of linguistic recuperation and many of the rhetorical devices of literature. Moreover, in the process of sifting through, and selecting from, lived experience, autobiography, too, renders the past as an interpreted expanse of time that is endowed with a fuller sense of meaning precisely by its reproduction as narrative. What Strindberg is claiming here, however, and it is a claim that numerous other autobiographers (including, for example, Edward Gibbon and Rétif de la Bretonne) have also put forward, is nothing less than the idea of his privileged access to the past he has lived as at once the subject and the object of the tale he has to tell. It is also an extremely neat way of defending the presumption that any man could be the author of his own life.

This tale, moreover, this story that he tells, is his history. It is hard, indeed well-nigh impossible, to keep these two words apart. Certainly Strindberg could not. For him History (except - and importantly - in parts of The Swedish People) was always a narrative - a story, or Geschichte as he described it in a letter he sent his German translator, Emil Schering, just prior to writing 'The Mysticism of World History', in which, after 'a rapid read through', he judged the course of world history to be 'a picaresque novel' [SS 54, 378]. But no more can the reader of The Son of a Servant readily distinguish history 
from story, particularly when confronted by a title page that announces ' $E$ n själs utvecklingshistoria 1849-67' (what the English translation, by Evert Sprinchorn, calls 'The Story of the Evolution of a Human Being'). ${ }^{4}$ For as this subtitle suggests, this story is part of history ('historia') and the evolution of the serving woman's son unfolds in the course of a specified historical period. Furthermore, of all Strindberg's autobiographical fictions, The Son of a Servant, with its sense of how the growth of the self is to be seen as part of a never-ceasing interplay with a developing world, comes closest to the classic works in the genre, which, as Karl Weintraub has pointed out, 'took on its full dimension and richness... [as] part of that great intellectual revolution marked by the emergence of the particular modern form of historical mindedness we call historism or historicism'. For Weintraub, whose concept of the dynamic relationship between the individual subject and the historical world underlies this 'historicized' approach to autobiography, the key work is Goethe's Dichtung und Wahrheit (Poetry and Truth, 1811-31) with its prefatory claim that the principle task of [auto]biography is to present a man in the conditions of his time, thus making it a matter of moment precisely when a man is born since - as Goethe writes - 'it can truthfully be said that any man, had he been born a mere ten years earlier or later might as far as his own formation and his outward achievement; are concerned, have become an entirely different person'. ${ }^{6}$ And just to confirm that he means what he writes, Goethe pointedly informs the reader in his opening sentence not only of the year, but of the month, day, and very hour at which he was born- as the clock struck twelve on 28 August 1749 .

In discussing The Son of a Servant with Gustaf af Geijerstam Strindberg himself regards the work as an "evolved" [utvecklad] form of the naturalist novel including historical, psychological, and social material' [V, 295; 1, 195]. Writing to Edvard Brandes with an easy use of the Swedish 'historia' to describe both history and story, he describes the book as

... the history of the epoch in one man's life... There will be five volumes, that is the whole story 1849-86. It will be the story of Sweden, the story of the making of a writer; the story of the origin and evolution of a soul during a particular period, the story of the nature and causes of the present culture sickness. Etc. [V, 339; 1, 202]

And again, he says (of the first volume):

It contains a full biography of a well-known and important writer with as little falsehood as the genre allows, and a domestic history of Sweden 49-67. The book will therefore help young people make sense of the immediate past without which it is impossible to understand the present $[\mathrm{V}, 314 ; 1,197]$. 
But this narrative doubles as a further item in the natural history of the human heart, to which Strindberg once told Siri von Essen all writing of value belonged [I, 198; 1, 43], and offers itself, moreover, as another contribution to the 'study of man' which Rousseau, in reflecting upon his Confessions (1781-88), saw as only just then beginning. In this respect, too, The Son of a Servant is conventional in its point of departure, even though its premises are offered more as a document humain in the archives of history and contemporary medical science than as a personal contribution to that library of autobiographical and confessional material which Herder had called for in his 'Von Erkennen und Empfinden der menschlichen Seele' (1792), but from which it is only a short step to the idea that Strindberg shared with Taine, namely, that if the conduct and thought of an individual was determined by the historical moment, the moment was itself illuminated by the various literary manifestations of an individual life to a far greater extent than by the kind of documents on which history customarily relied. As Taine observed, in the celebrated introduction to his Histoire de la littérature anglaise (1863):

I would give fifty volumes of charters and a hundred volumes of state papers for the memoirs of Cellini, the epistles of St Paul, the table-talk of Luther, or the comedies of Aristophanes.

However, Strindberg, in acting as his own historian in The Son of a Servant (perhaps more nearly his own natural historian) does more than merely present us in Johan with an account of his historical self - as distinct, that is from his writing self, August, and in contrast to the figure of 'Axel' with whom, in both novels and plays, he otherwise shares his experience during much of the 1880s. As the final volume makes plain, the book, like such other accounts of his own life as Inferno (1897) and even Alone (1903), is a response to a particular crisis in his life. In general, Strindberg turns to autobiography in extremis, when he is (imaginatively or in fact) 'confronting death' (inför döden) [SV 20, 376], as a means of establishing precisely where he is at the point of writing, and in order to make what seems like, but never entirely is, of course, a fresh beginning. In fact The Son of a Servant marks perhaps as crucial a moment in Strindberg's life as Inferno does; as he makes plain, it is written at least in part as a response to that sudden sense of apparent plotlessness induced in him by his encounter with scientific Darwinism and the atheism he associated with it, a world that seemed to him to be 'all just a higgledy-piggledy jumble of regulated chance and necessary caprice and in no way a planned creation' [SS 19, 244], a world represented - if it can be called that - by the empty, unsignifying space at which he gazed from the North Sea coast at Luc-sur-mer in Normandy in 1885 , with its horizon void of the rocks and islands by which his eye was accustomed to plot a course in the Stockholm archipelago. 
One of the main casualties of this experience was a belief in history as a meaningful sequence of events, a belief that had already been undermined by Strindberg's encounter some years previously with Eduard von Hartmann's pessimistic Philosophie des Unbewußten (Philosophy of the Unconscious, 1869). 'When he looked at life, and particularly at the course of history, he discovered only a series of circles and the repetition of delusions,' he remarks in The Son of a Servant on the impact that von Hartmann, whom he had helped his friend Anton Stuxberg translate into Swedish, had made on him. Now, when examining the evidence for evolution at the moment of writing in 1886, he again sees change, but no meaningful progress or development towards a discernible goal; rather, the image on which he falls back, the notion of a 'kretsgång', or circular motion, that he originally derives from Der Kreislauf des Lebens (1852) by the Dutch-Italian physiologist Jakob Moleschott (1822-93), whose theory of the random circulation of matter Strindberg claims to have encountered when he was only fifteen, once again suggests some pointless stasis or flux of being, rather than the coherence afforded by sequence and succession. ${ }^{8}$

And yet, having negotiated the horror vacui that consumes his hero Axel Borg at the close of By the Open Sea, and following the free fall of his own Inferno crisis, it becomes clear that it is partly history that provides Strindberg with at least a temporary means of recreating order in his life when he returns to literature at the end of the 1890s. Against the void or existential horror of the plotless moment, he places history, what the narrator of Graham Swift's novel Waterland calls 'the Grand Narrative', whereby man fills the vacuum he detects about him and dispels his own private fears (Swift's narrator, incidentally, is a historian and should perhaps know better). Man lives, he goes on, by telling stories:

... only animals live entirely in the Here and Now. Only nature knows neither memory nor history. But man - let me offer you a definition - is the story-telling animal. Wherever he goes he wants to leave behind not a chaotic wake, not an empty space, but the comforting marker-buoys and trail-signs of stories.?

Without narrative, without being the instigator and/or subject of a plot or story one is - as Scherherazade would find herself - dead, or at best given over to that endless, monotonous addition of day tacked on to day, which is the experience of Samuel Beckett's later protagonists (and even they tell stories). Moreover, history, which reduces men to characters and the complex past to events, and which, having happened, resembles nothing so much in its unfolding as a play (both Hegel and Kierkegaard agree on this, if on little else), offers one of the models of coherence whereby Strindberg recuperates his life; it provides him 
with a variety of plots and scenarios through which he reads the past not only of nations but of his own present life.

Not, of course, that this was something entirely unique to the post-Inferno period. If, in the stories of Swedish Destinies and Adventures that he wrote on and off between 1882 and 1890 Strindberg had, as he told the publisher Claes Looström, 'as always taken the warp from my own life' [VII, 154], so in the historical dramas, as he wrote, some twenty years later, of The Earl of Bjälbo (1909), he had 'made the principal characters live by taking blood and nerves out of my own life so that they became mine and are my own property' [SS 50, 298]. The partial disguise of history was in any case an option he sometimes adopted, as in Tschandala (1889) in which recent events too close for comfort in his own life with his family at Skovlyst in Denmark were dressed up in seventeenth-century costume, or in stories like 'A Witch' (En häxa) and 'Development' (Uveckling), in which he explored his own deeply personal conflicts at a historical remove. 'You must read a story called 'Development' in Vol. 2 of Swedish Destinies,' he urged Jonas Lie, in 1884, 'There you have me in 2 parts!' [IV, 194; 1, 147]. Even Master Olof he could call his 'biography' - in one of those disarming statements with which he sometimes appears to collapse the fictional into the autobiographical [IV, 165].

However, while it would be quite possible at this point to indulge in the pursuit of a series of more or less conceivable correlations between Strindberg and his fictional characters it is, rather, the way in which history offers him a series of plots or scenarios through which he establishes the contours of his life, even as he is living it, that is of real interest here - how, firstly, the stage of history affords a parallel series of fates, figurations of plot, and patterns of relationship, in which he continuously seeks to read his own life and locate himself, and then how - as something already composed and 'staged' - history resembles nothing so much as a play 'put on stage' (satt i scen) for him to contemplate, as indeed, in his later years, he often felt his own life to have been. In this respect, one may discern a neat community of interest between the working dramatist, accustomed in his history plays to dealing with finished lives and events that unfolded long ago, and the image of the drama dramatum in Kierkegaard's Concluding Unscientific Postscript of 1846, which, in offering Strindberg a view of the stage of history as one where God is the sole spectator, partly underlies his many late comments on the seeming theatricality of his own life. 'But world-history,' Kierkegaard writes,

is the royal stage where God is spectator, because he is not accidentally the only spectator, because he is the only one who can see. To this theatre no existing being has access. If he imagines himself a spectator here, he merely forgets that he is an actor... who must leave it to the royal spectator and actor how he will use him in the royal drama, drama dramatum..$^{10}$ 
Strindberg acknowledges the self-conscious theatricality of the history play as always to some extent a variation on a known theme by stressing the element of play, role play and performance in many of his later works, particularly Erik XIV (1899), Kristina (1901) and Gustav III (1902), while the enigma presented by the seeming theatricality of his own life emerges in his recurring speculations on the identity and purpose of the dramatist in whose plot he finds himself. As he asks himself in the Occult Diary (24 January 1901): 'Who stages these performances for us, and to what end.... Is it possible that all the terrible things I have experienced have been staged for me?'

Indeed, there is an unresolved but dramatically productive confusion as to who is the real dramatist in Strindberg's work, a confusion that dates back at least to Miss Julie and Creditors in 1888. However, before clarifying this confusion, it is worth pointing out that the nature of life as theatre is something on which Strindberg reflects in his later history plays as well as in relation to his own experience. Consider, for example, the way in which the once poorly regarded Gustav III operates both as a history play that focuses upon a series of events near the close of the reign of the historical Gustav III and as a dramatic meditation on history, more especially upon history as theatre. It is in fact impossible not to regard the self-reflexive nature of Gustav III, which comments both on its own nature as a play and on the theatricality of history itself, as central to its meaning and stage effect. And to achieve this ambiguity, Strindberg naturally exploits the fact that as a monarch his king was besotted with the theatre, himself a playwright given - or so Strindberg suggests - to extending his obsession with drama onto the stage of history, which he approaches in terms of the history plays of which he was so fond. Thus Gustav's decision to assume Dalecarlian costume in Act Two allows Strindberg to collapse the one into the other, since Gustav plans not only to don the attire and thereby take on the role of his heroic predecessor Gustav Vasa, but also, as it were, to take a leaf out of his own opera libretto on the subject, one written by the historical Gustav III in collaboration with the poet Johan Henrik Kellgren (1751-95), and first performed in 1786.

Moreover, as Matthew Wikander has pointed out, in his valuable study of historical drama from Shakespeare to Brecht, The Play of Truth and State, there is a further complex pattern of historical and theatrical allusion woven into the text of Gustav III through its many references to Caesar (both Shakespeare's and history's) and Caesar Augustus (once again both in terms of history and as a theatrical figure in Corneille's drama Cinna). Having once 'played Brutus and overthrown these homespun Caesars' [SV 48, 232], Gustav now finds himself cast in the role of Caesar. 'Oh, great Caesar, beware the Ides of March' [SV 48, 265], Fru Schröderheim says to him, theatrically attired in the costume of the fury Megaera, in Act Four, and when he congratulates himself on being 
'born with a caul and with Caesar's luck', the Queen responds by observing: 'Caesar's luck... wasn't there someone called Brutus?' [SV 48, 300]. At that moment the face of his future assassin, Anckarström, is glimpsed through an upstage window while the King, who recognizes an effective curtain line when he hears one, brings the play to a conclusion by repeating it with enthusiasm: '"Wasn't there someone called Brutus?" - That's superb! - Superb, Madam!' [SV 48, 301].

But Caesar is not Gustav's only role. He makes his dramatic entry to the conspirators at Huvudsta in Act Three quoting Corneille: 'Soyons amis, Cinna, c'est moi qui t'en convie' [SV 48, 249], a role that is later confirmed when the poet Bellman, having been addressed by the King as 'Horatius', responds by calling him 'Augustus' [SV 48, 268]. The implication in this pattern of allusions is, of course, that just as Shakespeare or Corneille followed history in writing their plays, so history, in the person of Gustav III, is to some extent rehearsing the theatrical scripts these dramatists have made of history. Moreover, this aspect of the play is compounded by the way in which Gustav is first seen as a playwright managing events and manipulating men, stage-managing as it were the cast of players at his disposal ('[he] has written a new play, with a leading role for you... very décolleté, Fru Schröderheim is told [SV 48, 228]), and then as an actor, forced to perform his role in a script he neither controls nor understands. The two are neatly combined in a crucial exchange with Armfelt about the developing intrigue in Act Two:

ARMFELT: That's not badly constructed, considered as a play!

THE KING: Who knows, perhaps it is a play, all of it!

ARMFELT: But the last act, have you got that?

THE KING: That will come of itself! [SV 48, 238]

In this anticipation of the end, as in the closing pages of the play, where Gustav is stalked by Anckerström, Strindberg creates one of his most theatrical effects because he can rely (at least in Scandinavia) on an audience knowing what in fact happened to Gustav III in history, while at the same time he impresses upon the spectator the irony of this 'endgame' situation in which (as in Beckett's play), a parallel is drawn between chess, play and theatre, between history and a game in which we are both player and pawn - or king and queen. Thus, 'Gustav, the player-king spends his final moments on stage moving in and out of danger in a way that specifically, visually, suggests the final moves of a game of chess. Anckarström's face at the window reminds us that the last move, which we will not see staged, must be checkmate.' ${ }^{11}$

However, so far as Strindberg's insertion of himself into the plot of history is concerned, what becomes evident is that while he may on occasion refer to one of his historical characters as representing his 'biography', he does so 
primarily in terms of what that figure's life may yield as a structuring device, an item in the available symbolic system of his culture that will enable him, through the teleology of plot, to transform the plotless flux of experience into the enduring substance of a text. It is not any simple identity between himself and Olof or Gustav Vasa or Erik XIV that he is after, but the possibility that, by matching his experience against theirs, by placing the puzzling scenario of his still problematic life against the one they have already lived, he will be able, as it were, to read his own story in their history.

Plots, whether in the novel or on stage, condense a life into a destiny, and autobiographers frequently date an unbroken consciousness of themselves to their earliest reading. According to Les mots, the young Sartre, for example, found pleasure and relief from the contingency of experience in the plot summaries of the plays and novels he found listed in Larousse, and in Book One of the Confessions Rousseau even dates his sense of continuous selfhood to the discovery, in both his mother's small library and in his grandfather's, of other exemplary plots by means of which he could create a kind of specular image of himself through identification and reverie. In Plutarch's Lives, for example, he discovered a number of models for the 'republican' author of the two Discours of 1750 that he would subsequently become.

In a sense this is what Strindberg does with history, although even Master Olof represents not so much an ego ideal that he is in search of as an attempt to trace what correlation there may be, if any, between his own experience and the trials that someone else has undergone. The same is also true of several other historical figures (Gustav Vasa, for example, King Magnus in The Saga of the Folkungs (1899) or - among his contemporaries - Alfred Dreyfus). But one sometimes detects a particular sense of satisfaction when the eye of the professional dramatist recognizes such turns of event in his future career as seem to confirm the plot with which he identified himself as a young man, a young man who had, as he maintains in Inferno, foreseen his fate at twenty, 'when I wrote my play Master Olof, which has shown itself to be the tragedy of my life' [SV 37, 293].

However, the 'emplotment' of his life in terms of history begins well before Strindberg starts to write either plays or stories on historical subjects. For just as his correspondence reveals him as ever alert to the way in which contemporary events constitute themselves naturally as literature in the form of novels, stories, or dramas, so in his letters he likewise catches their drift in parallels with history. Thus, long before he writes Carl XII (Charles XII, 1901) - even before he embarks upon a study of this Yeatsian anti-self in the story 'At the Wake in Tistedalen' (1891) - he uses the figure of the king he otherwise calls 'the great criminal' to map out his own situation, as when, in 1888, he writes to Verner von Heidenstam from Skovlyst in Denmark: 'I've pitched my 
Bender here and await a Narva or a Fredrikshald, in order to make my entry into Sweden' [VII, 87; 1, 276 - the allusions are to Karl XII's victory over Peter the Great at Narva, his five-year exile at Bender in Bessarabia, and his death at Fredrikshald in Norway]. Similarly, before he contemplates writing Gustav Adolf with its setting in the Thirty Years War, he explores his relationship with his Austrian relatives in historical terms, as a conflict between Catholic and Protestant, or uses the Uhl family to spin an elaborate web of parallel events between his own fate and that of Napoleon. ${ }^{12}$

It may seem a major step from such allusions to history in the letters, which are, it must be admitted, partly playful, to the larger structures of the later history plays. And yet what is at issue in both cases is a possible correspondence between the text of history and his own experience. Swedish history as a whole or in its constituent parts such as the Vasa Saga or the Saga of the Folkungs, offers him a canvas of some seven and a half centuries through which to explore the possibility of a causal pattern amidst the complex detail of sometimes apparently chaotic and discontinuous events. It is a considerable block of time - far exceeding the individual life he had explored in The Son of a Servant-in which he can try out the scenarios of guilt and suffering, nemesis, crime and punishment that he had previously examined in the context of his own life.

Some plays - Gustav Vasa, Gustav Adolf, even The Saga of the Folkungs yield these patterns of meaning quite readily. The 'miracle story' aspect of Gustav Vasa's life, for example, is one on which Strindberg himself comments: 'how God led him out of Danish captivity up to Dalarna, and how, after many dangers, he finally freed his country from bondage' [SV 41, 163]. The parallel with his own experience, as recounted in Inferno, To Damascus and elsewhere, is there to be made as one of several networks of allusion, including the Biblical and mythological, that suggest the existence of a suprahuman providential order in the affairs of men and nations, both past and (therefore) present. Other plays - Erik XIV and Carl XII, for example - seem to yield no such ready structure. Indeed, the former has been seen (by Michael Kaufman) as an ironic critique of traditional nineteenth-century historicism in its scepticism about coherent designs in history and modern precisely in its sense of the 'discontinuous, fragmented and chaotic, where the only principles of order inhere in the mind of the individual perceiver... a history stripped of all illusions of providential order, [and] emptied of teleology or regeneration. ${ }^{13}$ Although it is probably more correct to say that the spectator is not supposed to regard this disorder as necessarily inherent in history but as lying in the inability of the blind and unbelieving participants in the events depicted to perceive their purpose, the dramatic thrust is, nevertheless, to portray the protagonists as grotesque figures passively borne by forces they can neither control nor understand, the playthings of chance, like the limp doll on which the action of Erik XIVhinges 
Strindberg, however, may have it both ways, for, as always, the dramatist can explore the possibilities inherent in different standpoints. On the one hand, there is a world in which everything adds up, as in Gustav Vasa; on the other, a world in which the characters suffer a bewildering series of reversals and come out at a loss. But as in the naturalist plays, in which he sought to examine 'the raw, cynical spectacle that life offers' [my italics, SV 27, 102] on the supposition that there was no recognized divine masterplot, the disturbing question still remains: who is the scriptwriter? Who, if anyone, writes the plot, whether of history as a whole, or of an individual life?

For the period following the Inferno crisis, the answer would seem to be straightforward. Or at least, Strindberg offers two very clear and ready replies. In a discussion of Shakespeare's Julius Caesar, he declares that 'History in the large is Providence's own composition' [SS 50, 114], while in 'The Mysticism of World History' he maintains that synchronicity is the distinguishing feature of a world governed by order and design as opposed to disorder and chance. Thus, in both Crimes and Crimes (1899) or To Damascus on the one hand, and Gustav Vasa or Erik XIV on the other, the meaningful order of the emplotted scenes predicates the ordering presence of a master playwright, whether the protagonists can see this or not. ${ }^{14}$ As Strindberg explains, to his old friend Leopold Littmansson, regarding the structure of Crimes and Crimes: 'The dénouement! Yes, you see, the hero of my play, the plot master, is the Invisible One (God)' [XIII, 120].

However, this standpoint does not hold for long, even as regards the history plays, and the positions adopted by the mature Naturalist and the ageing Providentialist ultimately complement each other. With Miss Julie, for whom existence is 'a scum that drifts, drifts, across the water, until it sinks' [SV 27, 135], the very notion of a plotted life was placed in doubt. And yet, only a few weeks later, when he wrote Creditors, the insistent question concerning who in fact is directing the intrigue in the play, who (in the absence of God) conducts the audit, dispenses justice, and balances the accounts in a dramatic structure that is itself the perfectly balanced vehicle of the intrigue it depicts. Thus when, at the end of the play, Tekla accuses her ex-husband, Gustaf, of harbouring 'a villainous plan to destroy my happiness', he replies by rejecting any idea of a plot in both the literary and the secret or underhanded senses of the word. Things merely turned out as circumstance and situation ordained. He chanced to see her on a steamer; Adolf, her new husband, provoked him by recalling the book in which she had branded him an idiot; and even when he was confronted by her return, in Scene Two of the play, he declares that 'I didn't really know what I was going to say!' At which point he adds, 'Like a chess player, I had a number of possible plans, but which one I used depended on the moves you made. One thing led to another; chance played a part; and so I had you ditched' [my italics - SV 27, 267]. 
Chance, maybe, and a game of chess, but in practice the result is highly theatrical, artificial even, in the patterned, formal arrangement of the three dialogues which go to make up a play that is characterized by an acute sense of the way in which people assume and exchange roles in the interplay of life. And it is this interplay that invites comparison with that second set of history plays, written between 1901-02, in which there is a shift from the Providentialist model informing Gustav Vasa and Erik XIV to one based upon the notion, advanced in 'The Mysticism of World History', that history is 'an enormous game of chess played by a single player who moves both black and white, takes when he ought to, makes plans for both sides, is for himself and against himself, thinks everything out in advance and has only one aim: to maintain balance and justice, while ending the match in a draw' [my italics SS 54, 353; SE 191].

Here, Strindberg's attempt at plotting a relationship between his historical protagonist and history in order to illuminate his own experience has failed, or, rather, it has taken on something of the modernist hue that originally seemed to be lacking in his treatment of history at the time. When Martin Lamm first took issue with the Scribean elements of Gustav III or saw in Strindberg's portrait of Queen Kristina only a bohemian cabaret artiste, he for once missed the point, not only of the elaborate political game that is being enacted in both plays, but also with regard to their metatheatrical dimension - the almost Pirandellian consciousness they have of themselves as plays, as theatre. Moreover, it is a consciousness that is also implicit in the structure and situation of Creditors. Gustav, the royal dramatist and actor; Karl XII, the marionette; and Kristina, the actress queen - all, like Gustaf the vivisector of Creditors, enact roles, play games, or are played with, and thus invite comparison with their author, the indefatigable intrigant Strindberg, for whom art habitually evokes notions of 'lek', or play. 'Thus Providence plays with those who would play Providence', says Arvid Horn, of Karl XII [SV 4 7, 139]. But he who plays 'providence' here as in any other of these plays, is Strindberg himself. Ultimately, the attempt to read his life in the fortunes of historical figures fails. Nevertheless, he finally shares his life with them in the game of art. And thus, as Emerson observed, in a passage from his essay on history that Strindberg had surely read: 'All history becomes subjective; in other words, there is properly no history, only biography'. ${ }^{15}$ 